\title{
SOCIAL MEDIA IN EDUCATION: THE ABSENT ATTENDEE
}

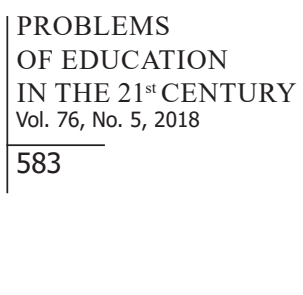

Saleh A. Alabdulkareem

King Saud University, Saudi Arabia

E-mail: dawerd@ksu.edu.sa

Interaction and Information technologies have reshaped our live today, and nowadays' students and teachers have a massive use of smart phones, iPads and other portable devices; moreover, they are continually looking for cutting edge technologies. But often the use of these devices is not in ways anticipated by technology proponents. All these smart phones and other portable devices are equipped or ready for social media applications like Facebook, Twitter, YouTube, WhatsApp, Telegram, and Instagram, Snapchat, which are part of what is known as Social Web 2.0, best characterized by the notions of social interaction, content sharing, and collective intelligence.

Daily news shows that the number of social network users is growing significantly worldwide; besides that, social networks capabilities are increasingly being leveraged effectively. Moreover, social networks are becoming less complex and more accessible; where young and older people can create and share content and interact easily through social networks. "Social connections affect so many aspects of our lives that our argument that they can also be applied to education and learning should be no surprise" (King and Sen, 2013, p.622). The role of emerging social media may offer new opportunities to enhance the teaching and learning experiences.

Social media can be defined as "a group of Internet-based applications 'interactive platforms' that build on the ideological and technological foundations of Web 2.0 that allow the creation and exchanges of user-generated content." (Kaplan and Haenlein, 2008, in: Ralph and Ralph, 2013, p. 451). Social media can include text, audio, video, images, podcasts, and other multimedia communications. Social media then, includes the various online technology tools that enable people to communicate easily via the internet and to share information and resources. Social media plays major role in developing social interactions between students and the society in general, that means widening the limits of teaching from class walls to be within the community.

School's aim is to develop and to support methods to improve the effectiveness and efficiency of interaction and collaboration among students, and with their teachers. Most of web social media tools have been developed in order to maintain, manage, and improve social interactions between people where people can easily access, reuse or comment on content that is authored by others. The evolving learning environments are allowing students to learn anytime and anywhere (Wetzel, 2010). Educational research demonstrates convincingly that immediate and frequent feedback improves learning. The truthful learning requires daily social interactions between students and teachers from one side, and from the other side between students and the daily life events; "bridging the all-too-well-known gap between the classroom and the real world. The learning has meaning and relates to the real world because it is modeled on the systems of the real world" (Klopfer, Osterweil, Groff, \& Haas, 2009, p.9).

A report from the Pew Research Center (2010) revealed that $73 \%$ of teenagers use some forms of social networking by incorporating social media into the lives of students in the classrooms, instructors also incorporate the new literacy that has become part of the students' outof-school lives (Hahn, 2008; Casey \& Evans, 2011). Zepke and Leach (2010) conclude that motivation and student dispositions will influence their ability to engage in interactive learning. 
PROBLEMS

OF EDUCATION

IN THE $21^{\text {st }}$ CENTURY Vol. 76, No. 5,2018

584 on computers, game consoles, digital music players, video cameras, cell phones, as well as the Web itself" (Jovanovic, Chiong, \& Weise, 2012, p. 39).

Great deal of research in education provides evidence for the effectiveness of using social media technologies directly in the context of traditional education situations or online education. Some studies have demonstrated the benefits of online social interaction in the learning process. Positive aspects of online interaction with teachers and peers include the following: access to peer and expert knowledge, ability to receive feedback from teachers and peers, and an opportunity to reflect on the exchanged messages (Ellis, 2001). By expressing their thoughts, discussing and challenging the ideas of others, and working together towards a group solution to a given problem, students develop critical thinking skills as well as skills of self-reflection and co-construction of knowledge and meaning (Brindley, Walti, \& Blaschke, 2009).

However, researchers and practitioners alike have found that interactions cannot be easily established in a learning environment. This often comes as a result of an inappropriate course design (Brindley et al., 2009) and/or the students' lack of collaboration skills, such as decision-making, consensus building, and dealing with conflict (Finegold \& Cooke, 2006). Therefore, in order to yield the expected educational benefits, the technology in general and social networking tools in particular have to be accompanied with a sound pedagogical approach (Jovanovic et al, 2012, p. 40).

Enhancing the appropriate use of media information among students requires that teachers themselves become media and information literate; this will enhance capacities to empower students with their efforts in learning to learn, learning autonomously, and pursuing lifelong learning. By educating students to become media and information literate, teachers would be responding first to their role as advocates of an informed and rational citizenry, and second, they would be responding to changes in their role as educators, as teaching moves away from being teacher-centered to becoming more learner-centered (Wilson, et al, 2011, p. 17). Teachers are more likely to embrace the use of information and media tools if it connects with pedagogical strategies that improve how they teach traditional school subjects.

Teachers would need to become interdisciplinary facilitators of student creativity, readily able to guide learning toward intended outcomes while creating legitimate space for experimentation. Social media would allow students to create and test knowledge claims. Social media would extend communication networks, provide immediate access to information, and facilitate new forms of creative expression. (Halverson \& Smith, 2009).

King and Sen (2013) highlighted three learning principles related to social connections in teaching: Principle 1: Social Connections Motivate, that means getting students to take actions that involve social interaction or that benefit the community -such as recycling- is often far easier. Principle 2: Teaching Teaches the Teacher, where in traditional teaching situation the difficulty of mind wandering instead of being engaged socially, cannot help students learn, to say nothing about teaching evaluations. Principle 3: Instant Feedback Improves Learning, where immediate and frequent feedback improves learning and teaching as well.

It is normal for parents and teachers to hesitate in using social media and digital devices like smart phones due to the possible negative impacts. Popular social websites have received intense backlash from schools which are fearful for the online safety of students using these sites, as well as the concern that students will misuse them during what is supposed to be instructional time. As a result, numerous alternative sites have emerged to provide teachers with more suitable platforms to host classroom online communities; also teachers can create their own private social network housed within trusted sites (Klopfer, et al, 2009, p.10). Hemmi, Bayne and Land (2009) maintain that students already collaborate, search for information, communicate and socialize using web technologies as part of their everyday lives, there is no reason not to use the same skills and behaviors in the classroom to support learning.

Although that there is a common agreement, that social media has such an impact on enabling the interaction between people, usually teachers and students use it in issues not related 
to study, like following them on social network that represent daily life activates. The idea that school assignments must be done in a formal format "usually papers" has a deep impact on preventing teachers from asking their students to use their portable devices for completing assignment purposes. For the public-school students, the common use of smart phones is centered around playing games on the internet frequently, and seldom to use it in issues related to their study, like class discussions, using educational forums, contact or personal experience with educational services providers, including consolations. Normally, the teachers and the students see a positive impact of social media on education and agree that using their smart phones could give more enjoyment to learning. In the meantime, there is some anxiety about using social media in education, related to teachers concern about the possibilities of adapting inappropriate social behaviors by the students when using social media widely (Alabdulkareem, 2015).

Using social media could have a major impact on class ability to share ideas anytime, so they can apply learning in new situations, and connect their daily life with curriculum. Moreover, using social media could enhance the relationship between school and home, and give easy access to both sides to reach others, and safe time and efforts.

It is very important to investigate the use of social media in teaching and learning as a scaffolding tool, and the impact of that on teachers teaching and students learning. Students can learn from informal learning situations, using what is available in students' hands, to build a meaningful learning experience in formal education.

Some of the negative aspects of using social media technologies seen as that these technologies for learning minimize the active participation of the learner; in fact, such technologies are developed so that they can work for any learner, regardless of the motivation or the ability of the particular learner. Technologies for learning are essentially teaching technologies structured to reliably deliver and measure outcomes regardless of the context or the situation of the learner (Halverson \& Smith, 2009, p. 51).

There is an apprehension spread among most teachers and students, as well as parents, that if the cost of using social media in education, wasn't covered officially by the school or educational authorities, the project would collapse. But as we can see from the basic characteristics of school teachers and students almost worldwide, it is apparent that smart phones are the best possible device to enhance the use of social media in education, where normally teachers and most students have some kind of smart phones. And for the Internet access, usually it is available for the teachers and the students, in several options, like having Internet access at home, or free access in some public areas "malls, coffee shops, etc). On the controversy, the current uses of social media in schools are rare, and could be seen as an approach by independent teachers or researchers.

It is apparent that smart phones are the best possible device to enhance the use of social media in education, where almost all teachers and most of students own it. Both the teachers and the students are willing to use social media in education, and they believe it will enhance their educational experiences, but the practice is significantly low; in the meantime, there are agreements that the use of social media is for socialization only. The infrastructure is available, but the comprehension educational view is absent.

But we can come to a conclusion that our teachers and our students are not using the smart phones in an appropriate way. The infrastructure is available and handy with all the teachers and with the massive majority of the students, but the comprehension educational view is absent for both of them. This conclusion is supported by the fact that both the teachers and the students agree that they use social media for interaction with others, including other students and teachers, but for purposes other than education.

Both the teachers and the students need a series of training sessions to evaluate their own use of social media, and to enhance their abilities to use available properties.

\begin{tabular}{|l} 
PROBLEMS \\
OF EDUCATION \\
IN THE 21 $1^{\text {st }}$ CENTURY \\
Vol. 76, No. 5, 2018 \\
\hline 585
\end{tabular} 
Saleh A. ALABDULKAREEM. Social media in education: The absent attendee

\section{PROBLEMS \\ OF EDUCATION \\ IN THE $21^{\text {st }}$ CENTURY \\ Vol. 76, No. 5, 2018 \\ 586 \\ References}

Alabdulkareem, S. (2015). Exploring the use and the impacts of social media on teaching and learning science in Saudi. Procedia - Social and Behavioral Sciences, 182, 213-224.

Brindley, J., Walti, C., \& Blaschke, L. (2009). Creating effective collaborative learning groups in an online environment. The International Review of Research in Open and Distance Learning, 10 (3). Retrieved from http://www.irrodl.org/index.php/irrodl/article/view/675/1271.

Casey, G., \& Evans, T. (2011). Designing for learning: Online social networks as a classroom environment. The International Review of Research in Open and Distance Learning, 12 (7), 1-26.

Ellis, A. (2001). Student-centered collaborative learning via face-to-face and asynchronous online communication: What's the difference? In Proceedings of the 18th annual conference of the Australian society for computers in learning in tertiary education (169-177). Melbourne, Australia.

Finegold, A., \& Cooke, L. (2006). Exploring the attitudes, experiences and dynamics of interaction in on-line groups. The Internet and Higher Education, 9 (3), 201-215.

Hahn, J. (2008). Born digital: Understanding the first generation of digital natives. Library Journal, 133 (13), 105.

Halverson, R., \& Smith, A. (2009). How new technologies have (and have not) changed teaching and learning in schools. Journal of Computing in Teacher Education, 26 (2), 49-54.

Hemmi, A., Bayne, S., \& Land, R. (2009). The appropriation and repurposing of social technologies in higher education. Journal of Computer Assisted Learning, 25 (1), 19-30.

Jovanovic, J., Chiong, R., \& Weise, T. (2012). Social networking, teaching, and learning. Interdisciplinary Journal of Information, Knowledge, and Management, 7, 39-43.

Kaplan, A., Haenlein, M., \& Mason, R. (2008). E-learning and social networking handbook: Resources for higher education. In Ralph, M., \& Ralph, L. (2013). Weapons of mass instruction: The creative use of social media in improving pedagogy. Issues in informing science and information technology, Volume (10) (pp. 449-460). New York: Routledge.

King, G., \& Sen, M. (2013). The teacher: How social science research can improve teaching American political science association. PS: Political Science and Politics, 46 (3), 621-629.

Klopfer, E., Osterweil, S., Groff, J., \& Haas, J. (2009). The instructional power of digital games, social networking, simulations and how teachers can leverage them. The Education Arcade: Massachusetts Institute of Technology.

Pew Internet and American Life Project (2010). Social media and Mobile Internet use among teens and young adults. Retrieved from http://www.pewinternet.org/Reports/2010/Social-Media-andYoung-Adults.aspx.

Prensky, M. (2001). Digital natives, digital immigrants. On the Horizon, 9 (5), 1-6.

Jovanovic, J., Chiong, R., \& Weise, T. (2012). Social networking, teaching, and learning. Interdisciplinary Journal of Information, Knowledge, and Management, 7, 39-43. Retrieved from http://www. ijikm.org/Volume7/IJIKMv7p039-043Editorial572.pdf.

Wetzel, D. (2010) E-learning replaces the traditional model of teaching and learning. Retrieved from: http://suite101.com/article/elearning-replaces-the-traditional-model-of-teaching-and-learninga227736.

Wilson, C., Grizzle, A., Tuazon, R., Akyempong, K., \& Cheung, C. (2011). Media and information literacy curriculum for teachers (Ed. Alton Grizzle and Carolyn Wilson) the United Nations Educational, Scientific and Cultural Organization. Paris: France.

Zepke, N., \& Leach, L. (2010). Improving student engagement: Ten proposals for action. Active Learning in Higher Education, 11, 167- 177.

Received: October 12, 2018

Accepted: October 16, 2018

Saleh A. Alabdulkareem
PhD, Professor of Science Education, C\&I Department, College of Education, King Saud University, Riyadh, 11451 Saudi Arabia.

E-mail: dawerd@ksu.edu.sa

Website: http://orcid.org/0000-0002-0689-7555 